ARTICLE OPEN

\title{
The influence of the Atlantic multidecadal oscillation on the eastern Andes low-level jet and precipitation in South America
}

\author{
Charles Jones $^{1}$ and Leila M. V. Carvalho ${ }^{1}$
}

The South America low-level jet (SALLJ) on the eastern slopes of the Andes is a unique climatological feature in the continent. The SALLJ transports large amounts of moisture and controls the spatiotemporal variability of precipitation in southeast South America. This study shows a remarkable influence of the Atlantic Multidecadal Oscillation (AMO) on decadal-to-multidecadal variability of the SALLJ. The results show a consistent pattern in which active SALLJ days during negative AMO phases are associated with negative precipitation anomalies over northern Amazon and the Atlantic Intertropical Convergence Zone (ITCZ). Increased cross-equatorial flow over northwestern South America combined with the outflow associated with the atmospheric subsidence over the negative precipitation anomalies enhances northerly winds along the eastern slopes of the Andes and Amazon. This atmospheric circulation response, which is more prevalent in the austral winter, intensifies the SALLJ. In the exit region of the SALLJ over southern Brazil, Uruguay and northern Argentina, an anomalous low-level cyclonic circulation is associated with enhanced precipitation. The influence of the AMO on the SALL is consistent with paleo-proxy studies showing multidecadal changes in precipitation over the La Plata River drainage basin. The analysis shows that secular trends reinforce the SALLJ and precipitation patterns. Moreover, the study highlights the importance of natural variability (i.e., decadal-multidecadal variations) occurring within long-term trends in the mean state, possibly associated with global warming, and significant changes in the SALLJ and precipitation over South America.

npj Climate and Atmospheric Science (2018)1:40 ; doi:10.1038/s41612-018-0050-8

\section{INTRODUCTION}

Climate variability and change in South America affect millions of people and impact water resources, agriculture, economic activity, human health, ecosystems and biodiversity ${ }^{1-5}{ }_{-}$ENREF_1. In this context, the South American Monsoon System (SAMS) plays a central role in determining the climate of the continent. ${ }^{3,6-10}$ In addition, the South America low-level jet (SALLJ) on the eastern slopes of the Andes is a distinctive component in such variability ${ }^{11-13}$; the SALLJ transports large amounts of moisture, induces the formation of mesoscale convective systems and determines the spatiotemporal variability of precipitation in southeast South America. ${ }^{14-16}$ Unlike the boreal summer lowlevel jet on the east of the Rocky Mountains in North America, the SALLJ is present year-round exhibiting intraseasonal-tointerannual variations. ${ }^{11,17}$

While the variability of the SALL on diurnal, synoptic, seasonal, and interannual time scales has been investigated before, ${ }^{11,17}$ mechanisms driving decadal-to-multidecadal (i.e., low-frequency) variations in the SALLJ have not been previously explored. This study investigates the relationships between the Atlantic Multidecadal Oscillation (AMO) ${ }^{18-20}$ and low-frequency variations in the SALLJ. The AMO manifests itself as an internal mode of sea surface temperature (SST) variability such that positive phases are associated with warming in the North Atlantic and cooling in the equatorial Atlantic. ${ }^{21}$ Important linkages have been found between the AMO and seasonal climate variability over northeast Brazil $^{20,22,23}$, as well as over southern South America. ${ }^{24}$ Here, we show that the AMO has a remarkable control on decadal-tomultidecadal variability of the SALLJ. Furthermore, this study explores how low-frequency variations in the SALLJ are linked to precipitation anomalies on decadal-to-multidecadal scales over South America.

\section{RESULTS}

The seasonal climatology of winds at $850-\mathrm{hPa}$ and precipitation during SALLJ days in the austral summer and winter is shown in Fig. 1. As the winds flow over the continent, the strong topographic blocking effect of the Andes changes the wind direction to north-northeasterly along the eastern slopes of the Andes over Ecuador, Peru, and Bolivia. The SALLJ reaches maximum speeds near Bolivia on the eastern slopes of the Andes where the orographic orientation changes to northwest-southeast ("the elbow"). This maximum is present during the entire year, in contrast to low-level jets in other parts of the world (e.g., United States Great Plains jet). ${ }^{11}$ In the exit region of the SALLJ (Fig. 1a), particularly during spring and summer, vigorous mesoscale convective systems are frequently formed contributing to intense precipitation over northern Argentina, Paraguay, and southern Brazil. ${ }^{25}$ During winter (Fig. 1b), precipitation in the SALLJ exit region is also high but influenced by cold frontal systems propagating into subtropical South America. ${ }^{26}$

Although the ERA20C reanalysis only assimilates surface and mean sea level pressure, and surface marine wind observations, the seasonal climatology of the SALLJ from ERA20C is consistent with SALLJ climatologies from other reanalysis products. ${ }^{11,14}$ Additional comparisons of vertical wind profiles from ERA20C and radiosondes released in Santa Cruz de La Sierra (SC) and

${ }^{1}$ Department of Geography, University of California, Santa Barbara, California, USA

Correspondence: Charles Jones (cjones@eri.ucsb.edu)

Received: 6 June 2018 Accepted: 28 September 2018

Published online: 25 October 2018 
(a)

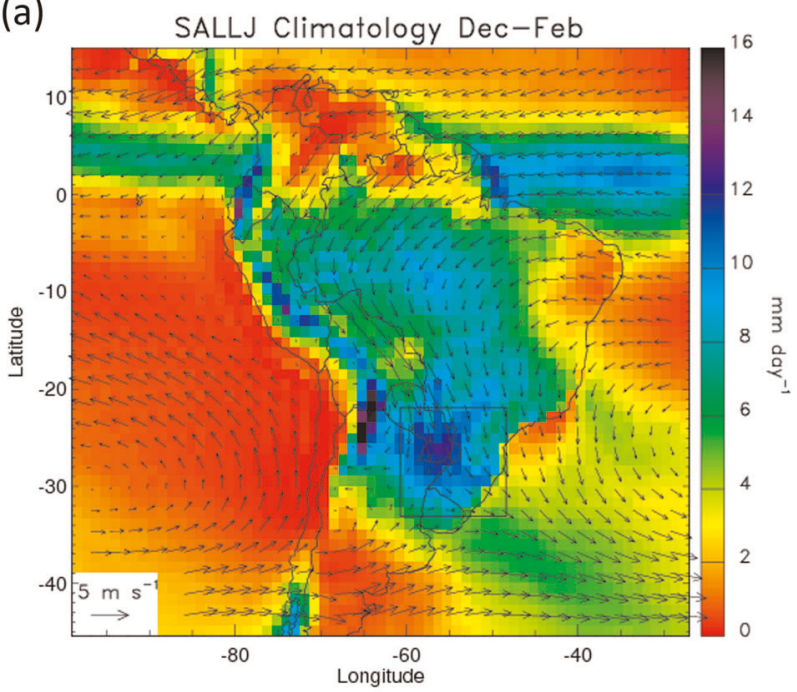

(b)

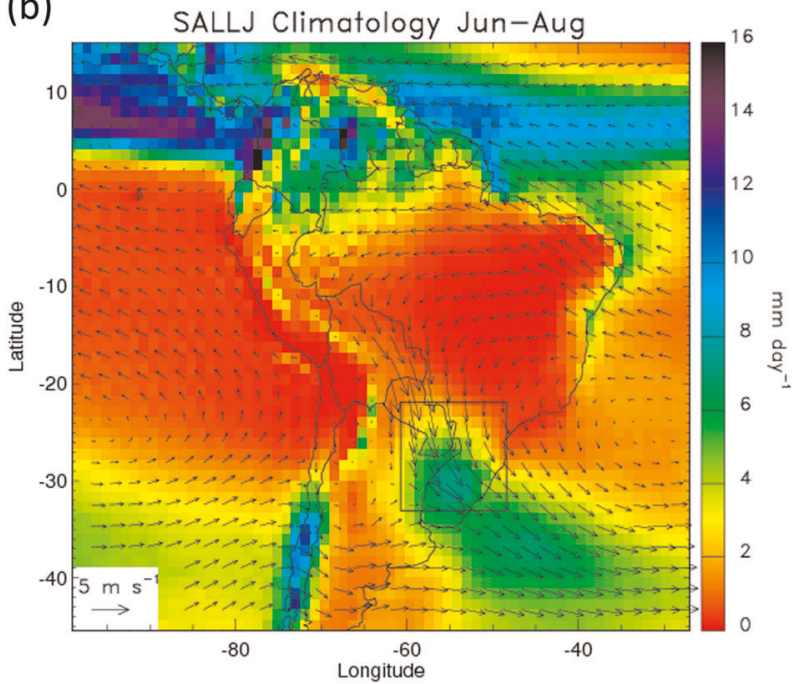

Fig. 1 Climatology of winds (850-hPa) derived from ERA20C reanalysis during a December-February 1900-2010 and b June-September 1900-2010. Color shading indicates precipitation during SALLJ days. Reference region (solid lines) is used to characterize multidecadal variations in precipitation over southern South America (Fig. 5)

Mariscal Estigarribia (MA) during the South American low-level jet experiment (SALLJEX) ${ }^{13}$ show that ERA20C is capable of reproducing the wind circulation where the SALLJ is most active (Supplementary Fig. S1). Other studies have also demonstrated the usefulness of ERA20C reanalysis to analyze climate variability in the period $1900-2010^{21}$.

Here we show that multidecadal variations in the AMO exhibit remarkable influences on multidecadal activity of the SALLJ in SC and MA (Fig. 2). Although, the relationships between the AMO and SALLJ are presented here considering the SALLJ activity during the entire year, the AMO influence on the SALLJ and precipitation patterns is stronger during the austral winter than in the summer as discussed later. The positive AMO phase during Sep 1924-Oct 1965 coincided with a period of low SALLJ activity in SC and MA (Fig. 2 top and middle). Likewise, the AMO shift to a negative phase in November 1965 approximately corresponded to increases in SALLJ activity in both locations. Interestingly, in addition to the multi-decadal shifts, negative correlations between AMO and SALLJ are observed on decadal time scales throughout
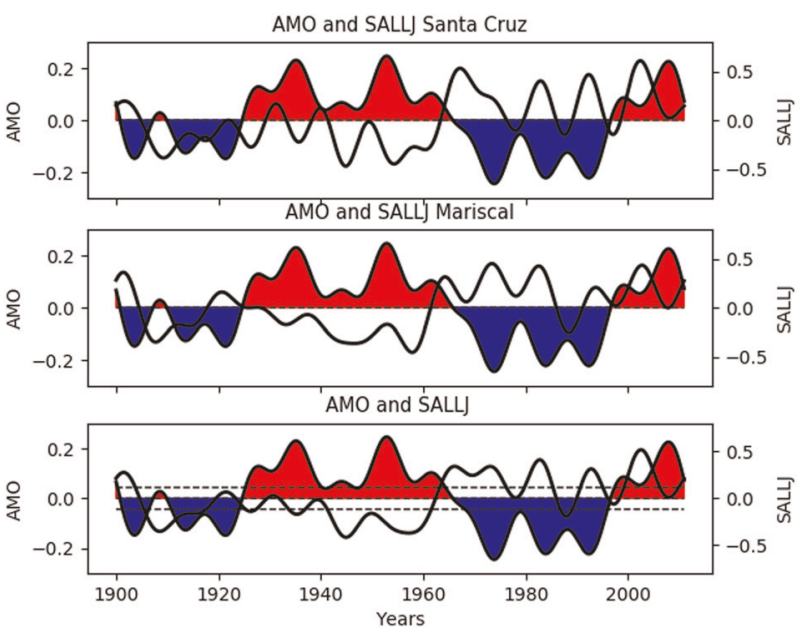

Fig. 2 Top: AMO index (Celsius) during January 1900-December 2010. Positive and negative AMO phases are indicated in red and blue, respectively. Top: black contour indicates normalized monthly SALLJ index over Santa Cruz de La Sierra, Bolivia. Correlation between indexes: -0.35 . Middle: as on top, but black contour shows normalized monthly SALLJ index over Mariscal Estigarribia, Paraguay. Correlation between indexes: -0.40 . Bottom: as on top, but black contour shows combined normalized SALLJ index. Dashed horizontal lines indicate 0.5 standard deviation of normalized SALLJ index and used to define periods of high/low SALLJ activity. Correlation between indexes: -0.40 . All indexes have been detrended and a low-pass filter has been applied to retain variations longer than 8 years

the record. Overall, the correlations between AMO and SALLJ indexes in SC and MA are -0.35 and -0.40 , respectively, which are statistically significant at $5 \%$ level. The correlation between the normalized SALLJ indexes in SC and MA is 0.75 revealing high spatial coherence in the SALLJ activity. The correlation between the AMO and a combined normalized SALLJ index between SC and MA (Fig. 2 bottom) is -0.40 (statistically significant at $5 \%$ level). The decadal maxima and minima in the combined normalized SALLJ index (Fig. 2 bottom) predominantly occur during the austral winter.

Figure $3 \mathrm{a}$ shows the difference in mean winds $(850-\mathrm{hPa})$ and precipitation during SALLJ days in the negative (Nov 1965-Aug 1996) minus positive (Sep 1924-Oct 1965) AMO phases. Time series of winds and precipitation in this calculation include longterm trends (Jan 1900-Dec 2010) possibly associated with global warming. Enhanced easterly winds are observed over Venezuela and along the eastern slopes of the Andes in Peru and Bolivia indicating enhanced SALLJ activity. Furthermore, statistically significant wind anomalies are seen over Brazil and an anomalous cyclonic circulation centered near Uruguay. Decreased precipitation occurs over the entire Intertropical Convergence Zone (ITCZ) in the Atlantic, while enhanced precipitation is observed over southwestern Amazon, southern Brazil and parts of Paraguay and northern Argentina. After removing long-term linear trends (Fig. $3 \mathrm{~b})$, a similar wind ( $850-\mathrm{hPa}$ ) pattern is noted over South America with enhanced SALLJ and the anomalous cyclonic circulation near Uruguay. Negative precipitation anomalies are observed over northern Amazon and off the coast in the western equatorial Atlantic. However, the extent of positive precipitation anomalies over southern Brazil decreases relative to Fig. 3a and enhanced precipitation occurs in the exit region of the SALLJ (Fig. 3b).

Calculations similar to Fig. $3 a$ have been performed but separating the data into extended austral summers (Nov-Mar) and winters (May-Sep) (Fig. S2). The results indicate a stronger influence of the AMO during winter than in summer seasons. This is particularly the case for cross equatorial wind anomalies over 

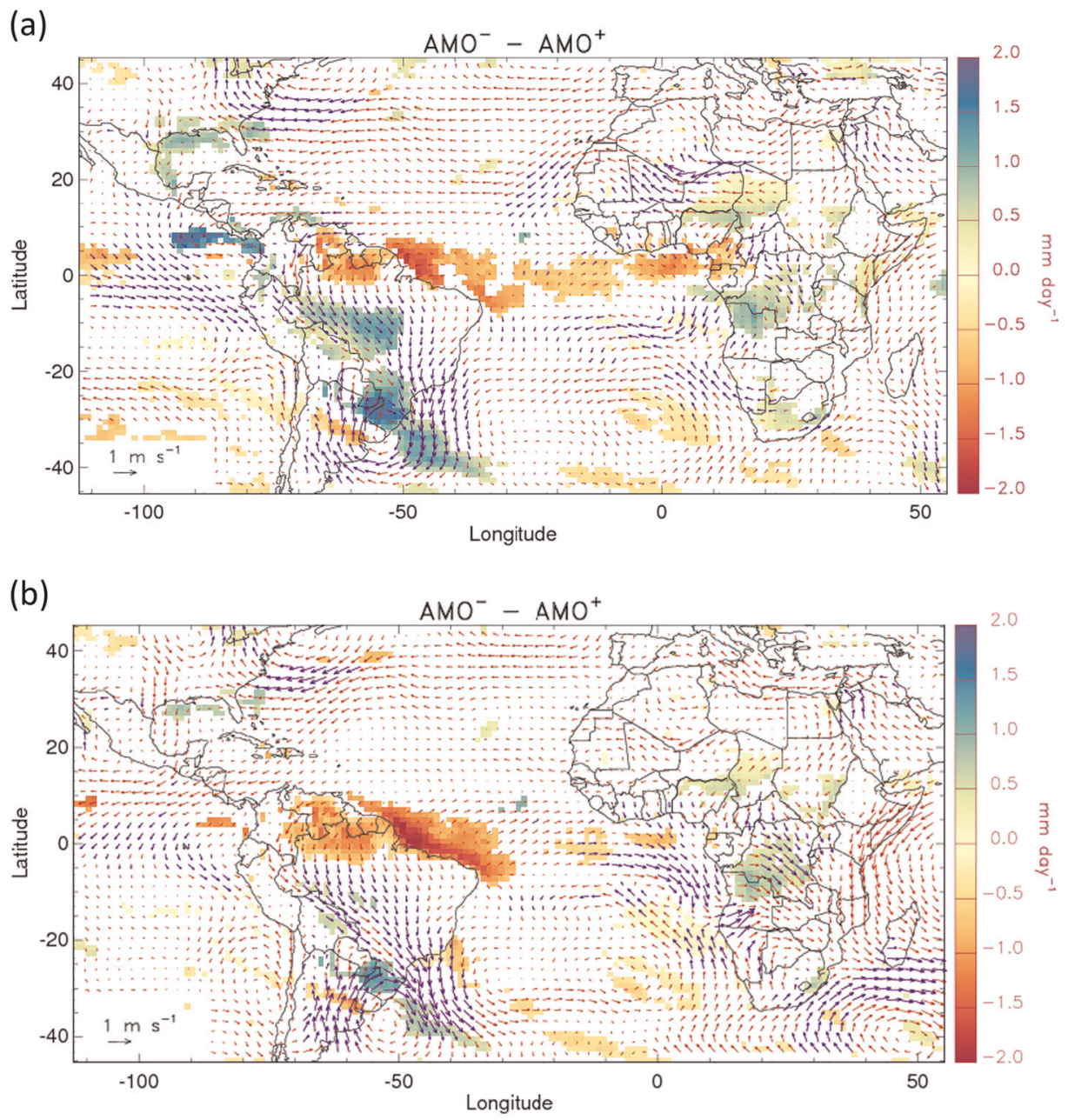

Fig. 3 a Differences in mean winds (850-hPa) and precipitation during SALLJ days between negative (Nov 1965-Aug 1996) and positive (Sep 1924-Oct 1965) AMO phases. Time series of winds and precipitation contain linear trends. $\mathbf{b}$ As in a, but linear trends in winds and precipitation have been removed before calculating the difference between negative and positive AMO phases. Vectors in blue colors are statistically significant at $5 \%$ confidence; vectors in red are not statistically significant. Vector scale is shown in the inset. Shading shows statistically significant $(5 \%$ level) differences in mean precipitation

northern South America and an elongated band of precipitation anomalies over Peru, Bolivia, Paraguay and southern Brazil (Fig. $\mathrm{S} 2 \mathrm{~b})$. Similar calculations of differences in mean winds $(700-\mathrm{hPa})$ and precipitation during SALLJ days in the negative minus positive AMO phases are shown in Supplementary Fig. S3. These results highlight the importance of natural variability (i.e., decadalmultidecadal variations) occurring within long-term changes in the mean state; the combined effects are associated with significant changes in the SALLJ and precipitation over South America.

In addition to changes in SALLJ activity associated with shifts in AMO phases (Fig. 2), the SALLJ shows decadal periods of enhanced/decreased activity. To characterize changes in winds (850-hPa) and precipitation, the combined multidecadal normalized SALL index (Fig. 2 bottom) was used to define periods of high ( $\geq 0.5$ standard deviation) and low ( $\leq-0.5$ standard deviation) SALLJ activity. Because of the multidecadal shift in SALLJ activity, these thresholds were chosen so that enough periods of decadal activity in the low-level jet are selected. The results are qualitatively similar if higher thresholds are used (i.e., \pm 1 standard deviations). Figure 4 shows the difference in mean winds (850$\mathrm{hPa}$ ) and precipitation during SALLJ in high (2011 days) and low (2215 days) decadal periods. Enhanced winds (850-hPa) over most of the Amazon, enhanced SALLJ and an anomalous cyclonic circulation over Uruguay and northeastern Argentina are observed. Furthermore, a large area of negative precipitation anomalies extends from the equatorial Atlantic to the northern Amazon, whereas positive precipitation anomalies over Paraguay and southern Brazil are noted in the exit region of the SALLJ.

The results above show a consistent influence of the AMO on multidecadal variability of precipitation over Paraguay and southern Brazil. To obtain a temporal view of this relationship, Fig. 5 shows the AMO index and multidecadal variations in mean precipitation over the reference region (Fig. 1) when the SALLJ is active. Interestingly, considering the entire Jan 1900-Dec 2010 period, the correlation between the two indexes is small $(-0.19)$ and not statistically significant. However, the correlation between the two indexes only when the AMO is in the negative phase is high $(-0.49)$ and statistically significant at $5 \%$ level. In contrast, the correlation between the two indexes during positive AMO phases is negligible $(-0.09)$. This reflects a more coherent relationship between negative AMO phases and decadal variability of precipitation in the reference region.

By definition, the AMO is identified with statistical methods focusing on multidecadal variations in SST anomalies over the North Atlantic $\left(0-65^{\circ} \mathrm{N}\right)$. To better characterize the relationships between the SALLJ and lower boundary forcing, Fig. 6 shows correlations between the combined multidecadal normalized 


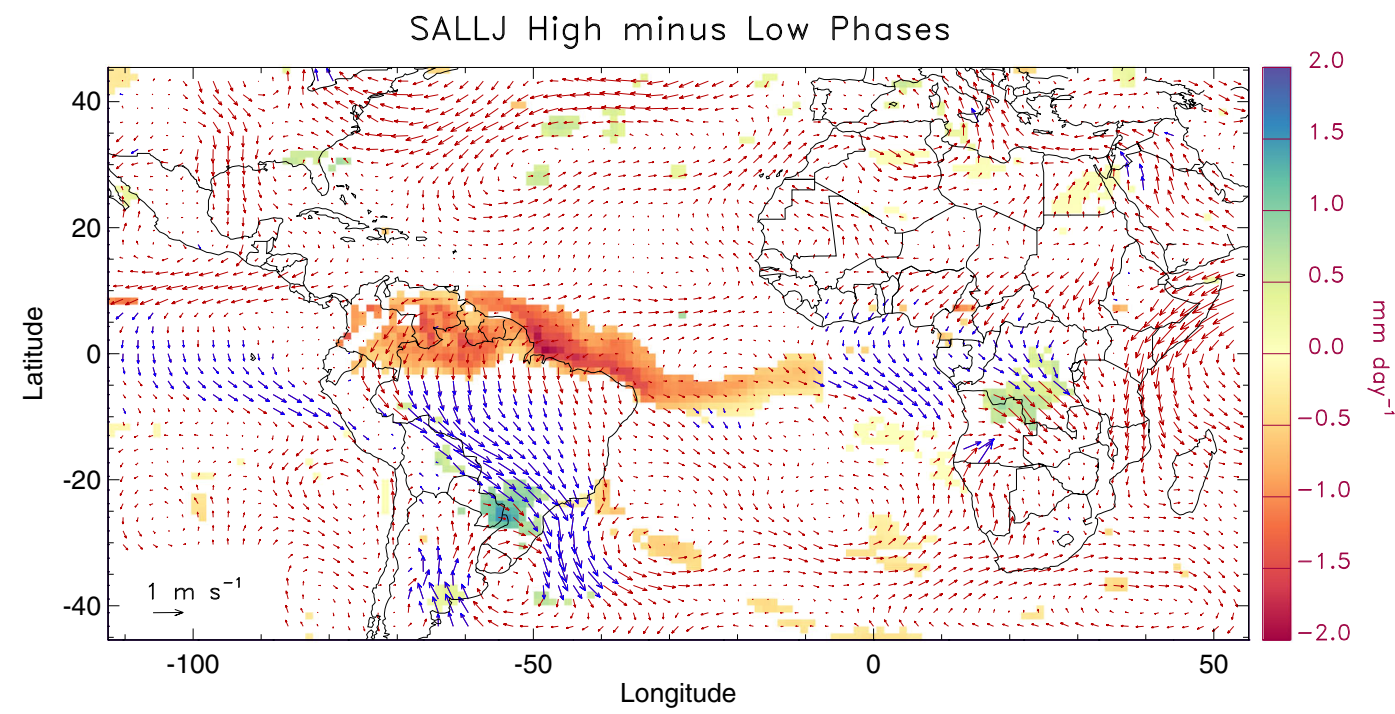

Fig. 4 Differences in mean winds (850-hPa) and precipitation during high and low decadal SALLJ activity. Vectors in blue colors are statistically significant at $5 \%$ confidence; vectors in red are not statistically significant. Vector scale is shown in the inset. Shading shows statistically significant $(5 \%$ level) differences in mean precipitation. Linear trends in winds and precipitation have been removed

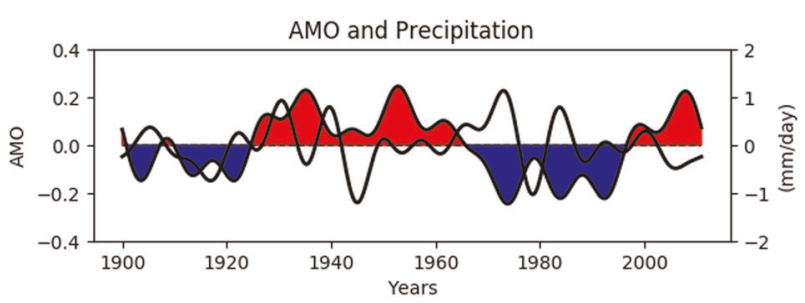

Fig. 5 AMO index (Celsius) during January 1900-December 2010. Positive and negative AMO phases are indicated in red and blue, respectively. Black contour indicates mean precipitation in reference region (Fig. 1) during SALLJ days. All indexes have been detrended and a low-pass filter has been applied to retain variations longer than 8 years

SALLJ index (Fig. 2 bottom) and low-frequency (i.e., period $\geq 8$ years) variations in SST. As expected, negative correlations are statistically significant over the North Atlantic; south of the equator in the Atlantic, correlations are positive but only significant off the coast of Brazil. In the Indian and Pacific Oceans, the correlation pattern is highly similar to SST anomalies associated with the AMO identified in other studies. ${ }^{27}$

\section{DISCUSSION}

The SALLJ is a key component of the climate in South America and this study investigated the variability of the low-level jet on decadal-to-multidecadal time scales. The low-frequency variability of the SALLJ is statistically correlated with AMO phases. The negative AMO phase during November 1965-August 1996 and positive phase during September 1924-October 1965 were associated with multidecadal regimes of high and low SALLJ activity, respectively. Furthermore, negative AMO phases on decadal time scales were related to periods of enhanced SALLJ decadal activity. This study shows a consistent pattern in which SALLJ days during negative AMO phases are associated with negative precipitation anomalies over northern Amazon and the ITCZ in the Atlantic. This pattern is associated with an increase in cross-equatorial flow over northwestern South America, which is combined with the outflow associated with the atmospheric subsidence over the region of negative precipitation anomalies over northern Amazon and off the northern coast of Brazil.
Additional analysis reveals that this influence of negative AMO phases is strongest during May-September. This atmospheric circulation response enhances low-level winds (850-hPa) along the eastern slopes of the Andes and, therefore, intensifies the SALLJ. In the exit region of the SALLJ over southern Brazil, Uruguay and northern Argentina, an anomalous low-level cyclonic circulation is associated with enhanced precipitation. The analysis shows atmospheric circulation and precipitation patterns with and without long-term linear trends. The patterns are similar spatially but long-term trends reinforce the magnitudes of winds $(850-\mathrm{hPa})$ and precipitation anomalies during decadal-to-multidecadal variability of the SALLJ. The effect of long-term trends on the SALLJ is consistent with significant warming in South America in recent decades. $1,28,29$

The results above raise the question: what is the mechanism associated with negative AMO phases and multidecadal changes in the SALLJ? A previously proposed mechanism for the SALLJ argues that the northerly flow along the eastern slopes of the Andes is forced by zonal pressure gradients associated with upstream troughs and westerly flows crossing the Andes. ${ }^{30}$ While the mechanism is supported by observations during austral winter, the results of this study show that this mechanism cannot explain decadal-to-multi-decadal changes in the SALLJ during negative AMO phases. The results of our study show an enhancement of the anti-cyclonic circulation in the south Pacific with subtropical wind anomalies off the coast of Chile flowing parallel to the mountains rather than cross-Andes (Supplementary Fig. S3).

The results presented here suggest that atmospheric circulation changes in the equatorial Atlantic forced by negative AMO phases might be the driving mechanism of low-frequency variations in the SALLJ. Some studies show substantial evidence that the AMO modulates the position of the ITCZ in the Pacific and Atlantic Oceans. ${ }^{22,24,31,32}$ In particular, Knight, et al. ${ }^{20}$ used a 1400 year run of the HadCM3 global climate model to analyze the variability of the AMO. Their results show that during positive AMO phases, SST gradients near the equator force a northward displacement of the ITCZ in the Atlantic. Conversely, SST gradients during negative AMO phases induce a southward displacement of the Atlantic ITCZ, such negative precipitation anomalies in the HadCM3 model extend from the northern parts of South America, Atlantic $\left(0-5^{\circ} \mathrm{N}\right)$ and Africa. A comparison between Fig. 3 and Fig. 1 from Knight, et al. $^{20}$ shows a remarkable agreement in the spatial pattern of 


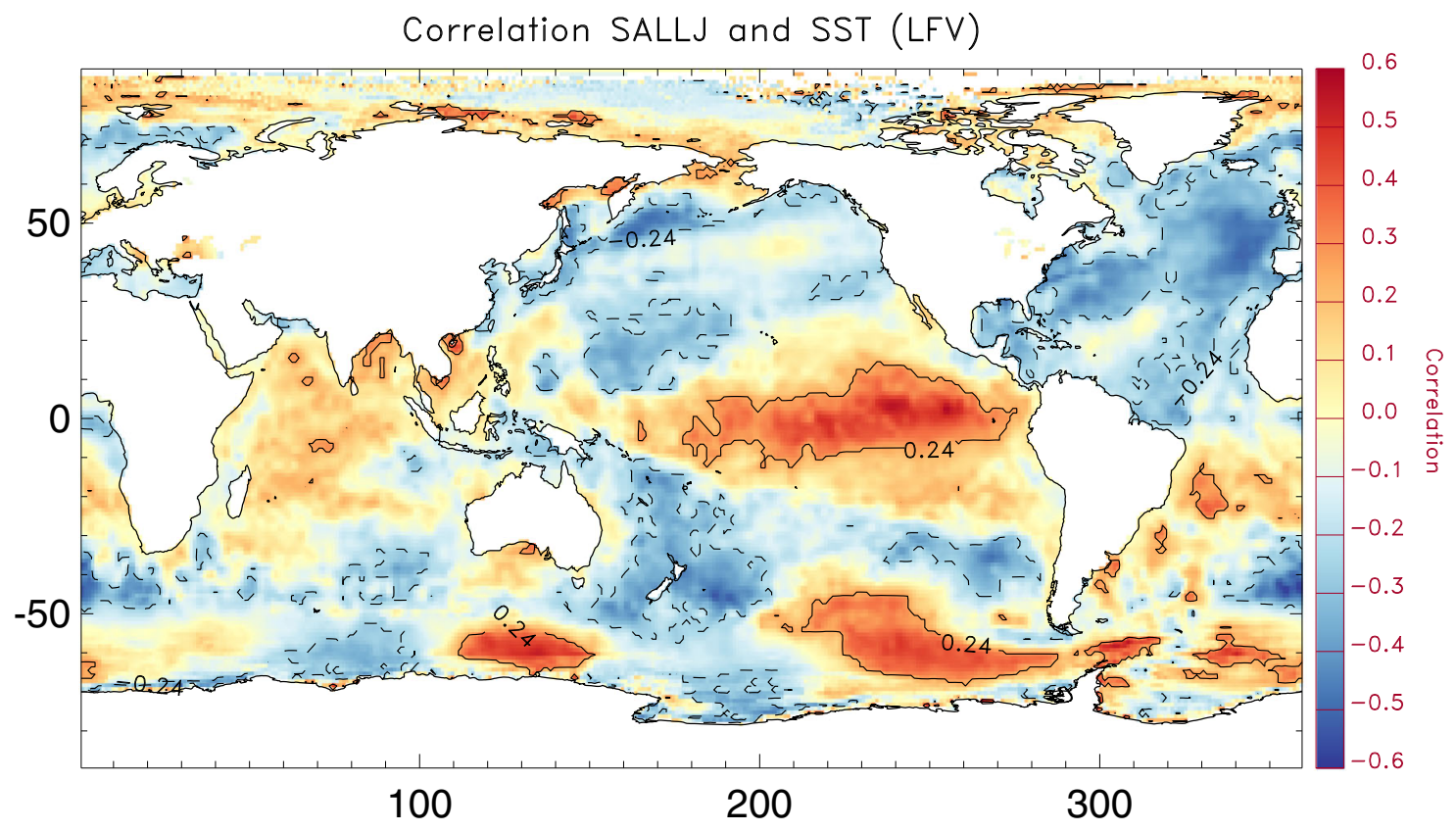

Fig. 6 Correlation between monthly values of combined normalized SALLJ index and sea surface temperature (SST). Annual cycle and linear trends in SST have been removed; time series were additionally filtered to retain only variations longer than 8 years. Correlations $\geq+0.23$ $(\leq-0.23)$ are statistically significant at $5 \%$ level and enclosed by solid (dashed) lines

negative precipitation anomalies described in this study. Also, the positive precipitation anomalies shown in Knight, et al. ${ }^{20}$ indicate a southward displacement of the ITCZ located south of the region of negative precipitation anomalies. These positive precipitation anomalies in the equatorial Atlantic are not observed in Fig. 3. We note, however, that our analysis focused on the joint activity of the SALLJ and AMO, while Knight, et al. ${ }^{20}$ examined only the variability of the AMO.

This study shows that the index developed to capture lowfrequency variations in the SALLJ is strongly correlated with the AMO. Furthermore, the correlation pattern between the SALLJ index and low-frequency variations in the SST show significant correlations over the Atlantic Ocean Basin. Over the Pacific Ocean, the correlation pattern highly resembles SST anomalies associated with the AMO. In addition to the results presented here, we have also investigated relationships between the PDO $^{33}$ and decadalto-multidecadal variations in the SALLJ (not shown). However, negligible correlations were found between PDO and SALLJ indexes. Thus, the relative roles of decadal-to-multi-decadal variations in SST anomalies in the Pacific Ocean relative to SST anomalies in the Atlantic Ocean remains to be investigated.

Another important consideration is that the relationships between the AMO and decadal-to-multidecadal variations in the SALLJ identified in this study can help the interpretation of paleoclimatic records in South America. Bernal et al., ${ }^{34}$ for instance, analyzed a high-resolution stalagmite record from the Botuverá Cave in southern Brazil. Wavelet analysis of the highresolution record shows intermittent $60-80$ year periodicities throughout the Holocene, which the authors attribute to a modulation of the AMO on the SAMS. The authors interpret the out of phase relationship between precipitation over northeastern and southeastern Brazil to mega north-south displacements of the South Atlantic Convergence Zone (SACZ). However, the Botuverá Cave is situated near the region of enhanced precipitation shown in Figs. 3 and 4. Alternatively, the precipitation variability inferred from the stalagmite record in southern Brazil can be interpreted as increased decadal-to-multidecadal activity of the SALLJ during negative AMO phases as shown in this study. Additionally, Chiessi, et al. ${ }^{35}$ measured stable oxygen composition of planktic foraminifera and titanium intensity in sediments to derive a 4500 year proxy record of discharge in the La Plata River drainage basin. Spectral and wavelet analyses show a periodicity of about 64 years in the proxy record, which the authors attribute to an influence of the AMO on the SAMS. This study shows a direct link between decadal-to-multidecadal activity of the SALLJ during negative AMO phases and enhanced precipitation over Paraguay, southern Brazil and northern Argentina. As the results of this study suggest, the enhanced precipitation over southeast South America increases sediment flow over the La Plata River drainage basin.

The question of how increases in greenhouse gases and global warming project on the $\mathrm{AMO}$ and, consequently, may modify decadal-to-multidecadal activity in the SALLJ is of significant interest. Several studies have shown substantial long-term warming over South America especially over the Andes. ${ }^{28,36}$ Understanding the dynamical mechanisms associated with natural variability (e.g., AMO), regional processes (e.g., SALLJ) and modifications induced by global warming is necessary to increase the confidence about future projections of climate change in South America. Advances in these research issues can bring significant benefits to society to cope with the effects of climate change.

\section{METHODS}

The European Centre for Medium-Range Weather Forecast Reanalysis of the 20th Century (ERA20C) ${ }^{37,38}$ was used to characterize the multidecadal variability of the SALL and precipitation over South America. ERA20C has approximately $125 \mathrm{~km}$ horizontal grid spacing and is available every $3 \mathrm{~h}$ (00-21UTC). Zonal and meridional components of the wind at $850-\mathrm{hPa}$ (U850, V850) and 700-hPa (U700, V700), and precipitation were used from January 1900 to December 2010. Occurrences of SALLJ were identified in Santa Cruz de La Sierra (SC) $\left(63^{\circ} 9^{\prime} 21.96^{\prime \prime}\right.$ W; $17^{\circ} 48^{\prime} 52.74^{\prime \prime}$ S) and Mariscal Estigarribia (MA) $\left(60^{\circ} 37^{\prime} 0.84^{\prime \prime}\right.$ W; $22^{\circ} 2^{\prime} 11.94^{\prime \prime}$ S); previous studies have shown that these locations represent the SALL variability. ${ }^{11,13,14}$

Since the spatial density of rain gauges in South America is low before the $1980 \mathrm{~s}$, particularly over the Amazon, precipitation from ERA20C is used here to analyze the relationships between the AMO and decadal-tomultidecadal variations in the SALLJ. A comparison between ERA20C and 
GPCP (Global Precipitation Climatology Project) ${ }^{39}$ precipitation is shown in Fig. S4. High correlations between both datasets are seen over most regions in South America, which gives some confidence in the usage of ERA20C to infer the influence of the AMO on decadal-to-multidecadal variations in the SALLJ and precipitation.

Precipitation from ERA20C was also compared with rain gauge data in Fortaleza (3.7S, 38.5W) and Quixeramobim (5.3S, 39.3W) during 1900-2002. The rain gauge data are part of the World Monthly Surface Station Climatology and the time series used here were made available by the Joint Institute for the Study of the Atmosphere and Ocean at the University of Washington (https://jisao.uw.edu/). Correlations between ERA20C and rain gauge data are 0.77 and 0.75 in Fortaleza and Quixeramobim, respectively, lending additional confidence in the use of ERA20C.

The identification of SALL occurrences was performed in the following way. Nighttime time series of U850, V850, U700, V700, wind speeds at 850$\mathrm{hPa}$ and $700-\mathrm{hPa}$, and wind shear between $850-\mathrm{hPa}$ and $700-\mathrm{hPa}$ (SHEAR $850-700$ ) were computed by averaging data at 00,03 , and 06 UTC (i.e., 20:00 p.m., 23:00 p.m., and 02:00 a.m. Bolivia local time). These time series were calculated separately at SC and MA and obtained by averaging time series from four gridpoints around each location. To remove long-term trends possibly associated with global warming, each time series was detrended by removing a linear fit during January 1900-December 2010.

The 75th percentiles from the frequency distributions of U850, V850, wind speed at 850-hPa, and SHEAR 850-700 were determined for each season (Dec-Feb, Mar-May, Jun-Aug, and Sep-Nov) separately. A SALLJ event was defined when all conditions were met simultaneously: (1) wind speed at $850-\mathrm{hPa} \geq 75$ th seasonal percentile, (2) SHEAR $850-700 \geq 75$ th seasonal percentile, (3) V850 $<0$, and, (4) $|\mathrm{V} 850|>|\mathrm{U} 850|$. The frequencies of SALLJ days in SC and MA during January 1900--December 2010 were 8\% and $12 \%$ (number of SALLJ days divided by total number of days in the data record), respectively. The specification of seasonally dependent 75th percentiles ensures that the identification of SALL events are not biased by different magnitudes of winds and shear throughout the year; this methodology ensures a better representation of the SALLJ than the traditional method of fixed thresholds of wind speeds and wind shear. ${ }^{11,14}$

Normalized monthly indexes of SALL activity were constructed separately for SC and MA as follows: SALL $\sqcup_{\text {index }}(t)=\left[\frac{N(t)}{C N}\right] x\left[\frac{\mathrm{vS}(t)}{\mathrm{CV})}\right]$, where $N$ is the number of SALLJ days in the month $t, C N$ is the climatological number of SALLJ days in the month, VS is the mean wind speed $(850-\mathrm{hPa})$ of the SALL days in the month $t$ and CV is the climatological wind speed (850-hPa) of SALLJ days in the month. To focus on multidecadal variations in the SALLJ, the normalized SALL indexes in SC and MA were filtered in the frequency domain (using the FFT algorithm) and only variations longer than 8-years were retained. A combined low-frequency normalized SALL index was calculated as:

\section{$\operatorname{SALL}_{\text {index }}(t)=0.5 x\left[\mathrm{SALL}_{\text {index }} \mathrm{SC}+\mathrm{SALLJ}_{\text {index }} \mathrm{MA}_{\mathrm{MA}}\right]$}

, where SALL index SC $_{S C}$ and SALJ index $\mathrm{x}_{M A}$ are the individual indexes in SC and MA. These normalized indexes were used to characterize multidecadal variations in the SALLJ. Multidecadal variations in winds (850-hPa) and precipitation were analyzed by using daily time series calculated from 8 samples per day with and without long-term trends (i.e., removed by linear fits).

The Atlantic Multidecadal Oscillation (AMO) index of Trenberth and $\mathrm{Shea}^{40}$ was used here. The index is derived from detrended 10-year lowpass filtered sea surface temperature (SST) anomalies from HadISST data ${ }^{41}$ over the North Atlantic basin (0N-65N; 80W-0E). The AMO index was additionally filtered in the frequency domain retaining only variations longer than 8 years. Correlations between multidecadal variations in the AMO and normalized SALL indexes were performed; statistical significances were estimated using $t$-test and adjustments for effective sample sizes due to auto-correlations in the time series. ${ }^{42}$

Multidecadal changes in the SALL associated with the AMO were additionally examined by contrasting positive and negative AMO phases during Sep 1924-Oct 1965 and Nov 1965-Aug 1996, respectively. Statistical significance was estimated using differences in means with sample sizes adjusted because of auto-correlations in the time series. ${ }^{42}$ Changes in precipitation over southeast South America were examined using daily ERA20C. A monthly precipitation index was constructed by first computing the mean precipitation during days when the SALLJ was active in SC or MA. The resulting time series was detrended and filtered in frequency domain (using an FFT algorithm) retaining only variations longer than 8 years.

The relationship between the SALLJ and global SST was examined by computing the correlation between the combined low-frequency normalized SALL index and HadISST data. The annual cycle from monthly SST was first removed in each gridpoint and the resulting time series were detrended by removing linear fits during January 1900-December 2010. Low-frequency variations in SST were calculated by applying a filtering procedure using an FFT algorithm and retaining periods longer than 8 years. The statistical significance of correlations was estimated using adjustments for effective sample sizes due to auto-correlations in the time series.

To assess the accuracy of ERA20C in representing the atmospheric circulation in South America, vertical profiles of wind speeds from ERA20 were compared with radiosonde data in SC and MA during the South American low-level jet experiment (SALLJEX) during January-February $2003 .{ }^{13}$ While ERA20C shows weaker winds relative to radiosonde data, ERA20C vertical profiles are significantly correlated with observations including the pressure level of maximum wind speeds (Supplementary Fig. S1). Although ERA20C only assimilates surface and mean sea level pressure, and surface marine winds, ERA20C is capable of representing the vertical wind structure in the region where the SALLJ is active.

\section{Code availability}

Interactive Data Language (IDL) computer code was used for data processing and analyses. Computer codes are available from the author upon reasonable request.

\section{DATA AVAILABILITY}

The research presented here was derived from data sets that are all publicly available.

\section{ACKNOWLEDGEMENTS}

The ERA20 reanalysis were downloaded from the Research Data Archive at the National Center for Atmospheric Research, Computational and Information Systems Laboratory, Boulder, CO. [Available online at https://rda.ucar.edu/datasets/ds626.0]. The authors also thank the European Centre for Medium-Range Weather Forecasts (ECMWF) for making the ERA20 reanalysis available for this research. The HadSST data were obtained from the Met Office Hadley Centre. GPCP Precipitation data were provided by the NOAA/OAR/ESRL PSD, Boulder, Colorado, USA, from their Web site at https://www.esrl.noaa.gov/psd/.

\section{AUTHOR CONTRIBUTIONS}

C.J. defined the objectives of this study and was responsible for downloading the data and performing the analyses. He also wrote the initial versions of the paper. L.M. V.C. helped with literature review, results interpretation, and manuscript revisions.

\section{ADDITIONAL INFORMATION}

Supplementary information accompanies the paper on the npj Climate and Atmospheric Science website (https://doi.org/10.1038/s41612-018-0050-8).

Competing interests: The authors declare no competing interests.

Publisher's note: Springer Nature remains neutral with regard to jurisdictional claims in published maps and institutional affiliations.

\section{REFERENCES}

1. Carvalho, L. M. V. \& Cavalcanti, I. F. A. in The Monsoons and Climate Change: Observations and Modelling (eds Carvalho, L. M. V. \& Jones, C.) 253 pp. (Springer International Publishing, Springer Cham Heidelberg, New York, Dordrecht, London, 2016).

2. Carvalho, L. M. V. \& Jones, C. CMIP5 simulations of low-level tropospheric temperature and moisture over tropical Americas. J. Clim. 26, 6257-6286 (2013).

3. Marengo, J. A. et al. Recent developments on the South American monsoon system. Int. J. Climatol. 32, 1-21 (2012).

4. Vuille, M., Bradley, R. S., Werner, M. \& Keimig, F. 20th century climate change in the tropical Andes: observations and model results. Clim. Change 59, 75-99 (2003).

5. Liebmann, B. \& Mechoso, C. R. The South American Monsoon System. In: The Global Monsoon System: Research and Forecast, 2nd Edn. (ed. Chang, C. P. et al.) 550pp. (World Scientific Publishing, Singapore, 2010).

6. Vera, C. et al. Toward a unified view of the American Monsoon Systems. J. Clim. 19, 4977-5000 (2006). 
7. Mechoso, C. R., Robertson, A. W., Ropelewski, C. F. \& Grimm, A. M. in The American Monsoon Systems: An Introduction. (eds. Chang, C. -P., Wang, B. \& Lau, N. -C. G.) WMO/TD No. 1266 (TMRP Report No. 70), 197-206 (World Meteorological Organization, Geneva, Switzerland, 2005).

8. Garreaud, R. D., Vuille, M., Compagnucci, R. \& Marengo, J. Present-day South American climate. Palaeogeogr. Palaeoclimatol. Palaeoecol. 281, 180-195 (2009).

9. Robertson, A. W. \& Mechoso, C. R. Interannual and interdecadal variability of the South Atlantic convergence zone. Mon. Weather Rev. 128, 2947-2957 (2000).

10. Heidinger, H., Carvalho, L., Jones, C., Posadas, A. \& Quiroz, R. A new assessment in total and extreme rainfall trends over central and southern Peruvian Andes during 1965-2010. Int. J. Climatol. 38, e998-e1015 (2018).

11. Marengo, J. A., Soares, W. R., Saulo, C. \& Nicolini, M. Climatology of the low-level jet east of the Andes as derived from the NCEP-NCAR reanalyses: Characteristics and temporal variability. J. Clim. 17, 2261-2280 (2004).

12. Wang, H. \& Fu, R. Cross-equatorial flow and seasonal cycle of precipitation over South America. J. Clim. 15, 1591-1608 (2002).

13. Vera, C. et al. The South American low-level jet experiment. Bull. Am. Meteorol. Soc. 87, 63-77 (2006).

14. Nascimento, M. G., Herdies, D. L. \& de Souza, D. O. The South American water balance: the influence of low-level jets. J. Clim. 29, 1429-1449 (2016).

15. Sun, X. M. \& Barros, A. P. Isolating the role of surface evapotranspiration on moist convection along the Eastern Flanks of the tropical andes using a Quasi-idealized approach. J. Atmos. Sci. 72, 243-261 (2015).

16. Romatschke, U. \& Houze, R. A. Characteristics of precipitating convective systems accounting for the summer rainfall of tropical and subtropical South America. J. Hydrometeorol. 14, 25-46 (2013).

17. Liebmann, B., Kiladis, G. N., Vera, C. S., Saulo, A. C. \& Carvalho, L. M. V. Subseasonal variations of rainfall in South America in the vicinity of the low-level jet east of the Andes and comparison to those in the South Atlantic convergence zone. $J$. Clim. 17, 3829-3842 (2004).

18. Trenberth, K. E. Some effects of finite sample size and persistence on meteorological statistics. Part I: autocorrelations. Mon. Weather Rev. 112, 2359-2368 (1984).

19. Wang, S. -Y., Yoon, J. -H., Funk, C. C. \& Gillies, R. R. Climate Extremes: Patterns and Mechanisms. (John Wiley \& sons, American Geophysical Union, New Jersey, 2017).

20. Knight, J. R., Folland, C. K. \& Scaife, A. A. Climate impacts of the Atlantic Multidecadal Oscillation. Geophys. Res. Lett. 33, 10.1029/2006gl026242 (2006).

21. Martin-Rey, M., Polo, I., Rodriguez-Fonseca, B., Losada, T. \& Lazar, A. Is there evidence of changes in tropical Atlantic variability modes under AMO phases in the observational record? J. Clim. 31, 515-536 (2018).

22. Kayano, M. T., Capistrano, V. B., Andreoli, R. V. \& de Souza, R. A. F. A further analysis of the tropical Atlantic SST modes and their relations to north-eastern Brazil rainfall during different phases of Atlantic multidecadal oscillation. Int. J. Climatol. 36, 4006-4018 (2016).

23. Kayano, M. T., Valéria, A. R., Regina, G. S. \& Souza, A. F. A. How the two nodes of the tropical Atlantic sea surface temperature dipole relate the climate of the surrounding regions during austral autumn. Int. J. Clim. 38, 10.1002/joc.5545 (2018).

24. Seager, R. et al. Tropical oceanic causes of interannual to multidecadal precipitation variability in southeast south America over the past century. J. Clim. 23, 5517-5539 (2010).

25. Rasmussen, K. L. \& Houze, R. A. Convective initiation near the Andes in subtropical South America. Mon. Weather Rev. 144, 2351-2374 (2016).

26. Garreaud, R. D. Cold air incursions over subtropical South America: mean structure and dynamics. Mon. Weather Rev. 128, 2544-2559 (2000).
27. Deser, C., Alexander, M. A., Xie, S. P. \& Phillips, A. S. Sea surface temperature variability: patterns and mechanisms. Annu Rev. Mar. Sci. 2, 115-143 (2010).

28. Russell, A. M., Gnanadesikan, A. \& Zaitchik, B. Are the central Andes mountains a warming hot spot? J. Clim. 30, 3589-3608 (2017).

29. Carvalho, L. M. V. \& Jones, C. CMIP5 simulations of low-level tropospheric temperature and moisture over the tropical Americas. J. Clim. 26, 6257-6286 (2013).

30. Wang, H. \& Fu, R. Influence of cross-Andes flow on the South American low-level jet. J. Clim. 17, 1247-1262 (2004)

31. Levitus, S., Antonov, J. I., Boyer, T. P. \& Stephens, C. Warming of the world ocean. Science 287, 2225-2229 (2000).

32. Ruprich-Robert, Y. et al. Assessing the climate impacts of the observed atlantic multidecadal variability using the GFDL CM2.1 and NCAR CESM1 Global Coupled Models. J. Clim. 30, 2785-2810 (2017).

33. Mantua, N. J., Hare, S. R., Zhang, Y., Wallace, J. M. \& Francis, R. C. A pacific interdecadal climate oscillation with impacts on salmon production*. Bull. Am. Meteorol. Soc. 78, 1069-1080 (1997).

34. Bernal, J. P. et al. High-resolution Holocene South American monsoon history recorded by a speleothem from Botuverá Cave, Brazil. Earth Planet. Sci. Lett. 450, 186-196 (2016).

35. Chiessi, C. M., Mulitza, S., Pätzold, J., Wefer, G., \& Marengo, J. A. Possible impact of the Atlantic Multidecadal Oscillation on the South American summer monsoon. Geophys. Res. Lett. 36, L21707 (2009).

36. Carvalho, L. M. V. \& Jones, C. The Monsoons and Climate Change: Observations and Modelling. (Springer, Springer Cham Heidelberg, New York, Dordrecht, London, 2016).

37. European Centre for Medium-Range Weather, F. Research Data Archive at the National Center for Atmospheric Research. (Computational and Information Systems Laboratory, Boulder, 2014).

38. Poli, P. et al. ERA-20C: an atmospheric reanalysis of the twentieth century. J. Clim. 29, 4083-4097 (2016).

39. Huffman, G. J. et al. Global precipitation at one-degree daily resolution from multisatellite observations. J. Hydrometeorol. 2, 36-50 (2001).

40. Trenberth, K. E. \& Shea, D. J. Atlantic hurricanes and natural variability in 2005 Geophys. Res. Lett. 33, L12704 (2006).

41. Rayner, N. A. et al. Global analyses of sea surface temperature, sea ice, and night marine air temperature since the late nineteenth century. J. Geophys. Res. Atmos. 108, 4407 (2003)

42. Wilks, D. S. Statistical Methods in the Atmospheric Sciences. Second Edn., Vol. 91 (Academic Press, Inc., San Diego, 2011).

C Open Access This article is licensed under a Creative Commons Attribution 4.0 International License, which permits use, sharing, adaptation, distribution and reproduction in any medium or format, as long as you give appropriate credit to the original author(s) and the source, provide a link to the Creative Commons license, and indicate if changes were made. The images or other third party material in this article are included in the article's Creative Commons license, unless indicated otherwise in a credit line to the material. If material is not included in the article's Creative Commons license and your intended use is not permitted by statutory regulation or exceeds the permitted use, you will need to obtain permission directly from the copyright holder. To view a copy of this license, visit http://creativecommons. org/licenses/by/4.0/.

(c) The Author(s) 2018 